\title{
ASSESSMENT OF CORRELATION BETWEEN ACUTE VIRAL HEPATITIS AND SERUM LIPID LEVELS
}

\author{
Pavan D. Patel ${ }^{1}$, Nitin Jadhav², Shruti Nair 3 , D. M. Patel ${ }^{4}$, Aparna Patange ${ }^{5}$, Amit Botre 6
}

${ }_{1}^{1}$ Resident, Department of General Medicine, Krishna Institute of Medical Sciences, Karad, Maharashtra, India. ${ }^{2}$ Associate Professor, Department of General Medicine, Krishna Institute of Medical Sciences, Karad, Maharashtra, India. 3Tutor, Department of Physiology, Krishna Institute of Medical Sciences, Karad, Maharashtra, India. ${ }^{4}$ Associate Professor, Department of General Medicine, Vedanta Institute of Medical Sciences, Palghar, Maharashtra, India. ${ }_{5}^{5}$ Associate Professor, Department of General Medicine, Krishna Institute of Medical Sciences, Karad, Maharashtra, India. ${ }^{6}$ Assistant Professor, Department of General Medicine, Krishna Institute of Medical Sciences, Karad, Maharashtra, India.

\section{BACKGROUND}

ABSTRACT

As liver is an essential organ in lipid metabolism, several stages of lipid synthesis and transportation, it is reasonable to expect an abnormal lipid profile in those with severe liver dysfunction. There is prominent decline in plasma cholesterol and triglyceride (TG) in patients with severe hepatitis and hepatic failure because of reduction of lipoprotein biosynthesis. For reduced liver biosynthesis capacity, low levels of TG and cholesterol is usually observed in chronic liver diseases. This study was conducted to assess the correlation between acute viral hepatitis with serum cholesterol and serum triglyceride values.

\section{METHODS}

This case control study was, conducted among 30 presumptive cases of acute viral hepatitis, who were admitted under the department of general medicine, KIMS, Karad, during the period of October 2015 to March 2017. Probable cases of acute viral hepatitis having clinical symptoms suggestive of hepatitis or liver, consistent with Acute Viral Hepatitis, and those cases that were sero-positive for either Hepatitis-A, -B, -C or -E were included in the present study. Similar number of controls $(n=30)$ was selected in the present study. All the controls were matched for non-modifiable risk factors such as age and gender.

\section{RESULTS}

In this study, in patients with acute viral hepatitis in the acute phase, the mean total cholesterol was $169.700 \pm 33.225$, which was lower in cases than controls. Mean triglyceride was 151.066 \pm 53.677 , which was higher in cases than controls. The mean total cholesterol in cases was $32.730( \pm 37.863) \mathrm{mg} / \mathrm{dl}$ and mean value of triglyceride was $+29.933 \pm 75.019 \mathrm{mg} / \mathrm{dl}$.

\section{CONCLUSIONS}

There is a significant decrease in mean total cholesterol in acute phase, while the mean triglyceride value was statistically significantly higher during acute phase of viral hepatitis compared to controls.

HOW TO CITE THIS ARTICLE: Patel PD, Jadhav N, Nair S, et al. Assessment of correlation between acute viral hepatitis and serum lipid levels. J. Evolution Med. Dent. Sci. 2019;8(16):1331-1335, DOI: 10.14260/jemds/2019/296

\section{BACKGROUND}

Liver is the most important organ for the metabolism of lipids, lipoproteins and apolipoproteins. Under normal circumstances, most plasma endogenous lipids \& lipoproteins are synthesized in liver and then are secreted into the blood circulation. ${ }^{[1,2],[3]}$ According to previous researches, chronic liver disease with dysfunction interfere with lipid metabolism and it may alter plasma lipid and lipoprotein levels. [4]

Acute hepatitis may be defined by an inflammatory process of the liver persisting for less than six months. Hepatitis ' $\mathrm{C}$ ' virus (HCV) belonged to genus Hepacivirus, hepatitis B virus (HBV) or HCV accounts approximately $78 \%$ of hepatocellular carcinoma (HCC).[1],[2] As liver plays an important role in lipid metabolism, several stages of lipid synthesis and transportation. Therefore, it is reasonable to expect an abnormal lipid profile in those with severe liver dysfunction.

'Financial or Other Competing Interest': None.

Submission 01-01-2019, Peer Review 10-04-2019,

Acceptance 16-04-2019, Published 22-04-2019.

Corresponding Author:

Dr. Pavan D. Patel,

Department of Medicine,

Krishna Institute of Medical Sciences,

Karad, Satara-415110.

Maharashtra, India.

E-mail: researchexpert3@gmail.com

DOI: $10.14260 /$ jemds $/ 2019 / 296$

\section{(c) $($ ) $\ominus$}

There is prominent decline in plasma cholesterol and triglyceride (TG) levels in patients with severe hepatitis and hepatic failure because of reduction of lipoprotein biosynthesis. For reduced liver biosynthesis capacity, low levels of TG and cholesterol is usually observed in chronic liver diseases.

In clinical, the course of acute hepatitis may vary from mild symptom that does not require treatment to the fulminant hepatic failure that needs emergency liver transplantation. Acute viral hepatitis is more common to be asymptomatic in younger people. In addition, acute hepatitis may occur less commonly with infections such as EpsteinBarr virus, cytomegalovirus, adenovirus, herpes simplex and Coxsackie virus or with other non-infectious reasons. It is been demonstrated that in the acute and/or chronic liver diseases, hepatic function could be altered, and the lipids \& lipoproteins are not only present in abnormal amounts but they frequently also have abnormal composition including electrophoretic mobility and appearance.

Some researchers also found relationships between Hepatitis $\mathrm{C}$ and serum lipid levels. According to them, Lower serum cholesterol and LDL levels are found in patients infected with hepatitis $C$ when compared with patients with hepatitis B or without infection). Recent studies have shown that chronic hepatitis $\mathrm{C}$ infection is associated with decrease in cholesterol and LDL when compared with matched control subjects. 
The present study was conducted to assess the correlation between acute viral hepatitis with serum cholesterol level and serum triglyceride values.

\section{METHODS}

It was a case control study, conducted among 30 presumptive cases of acute viral hepatitis, who were admitted under medicine department, KIMS, Karad during the period of October 2015 to March 2017. The study was conducted after the clearance from institutional ethical committee.

Probable cases of acute viral hepatitis having clinical symptoms suggestive of hepatitis or liver consistent with Acute Viral Hepatitis, AND those cases that were seropositive for either Hepatitis-A, B, C or E admitted under department of medicine were included in the present study. Similar number of controls $(n=30)$ were selected in the present study. All the controls were matched for nonmodifiable risk factors such as age, gender.

With reference to the study conducted by Shweta et al, among cases of hepatitis, they observed mean SGOT values among cases as $495 \pm 115$, and among controls $578 \pm 90$. Using above reference values, at $95 \%$ confidence interval, and 90 power the sample size of 27 was calculated. Hence, we took 30 cases and 30 controls for the given study. All the study subjects were included after taking their consents.

\section{Inclusion Criteria \\ Cases}

30 Probable cases of acute viral hepatitis with clinical symptoms suggestive of hepatitis or liver consistent with Acute Viral Hepatitis, and those cases that were sero-positive for either Hepatitis-A, B, C or E, admitted under department of medicine, in a hospital were selected randomly (simple random sampling) and included in the present study.

- $\quad$ Probable Case of Acute Viral Hepatitis

Symptoms (Anorexia, Nausea, Vomiting, Alteration of taste, Arthralgia, Malaise in Prodromal phase. Dark urine, Pale colour stool, Prostration, Yellow eyes, Abdominal pain and Pruritus in Icteric phase) and Liver consistent with Acute Viral Hepatitis.

\section{- $\quad$ Recovering Phase of Acute Viral Hepatitis}

Absence of constitutional symptoms like anorexia, nausea, vomiting, fatigue, malaise and arthralgia. All the patients were enrolled after written and informed consent. Detailed history was taken. Thorough general and systemic examination was carried out. All findings were recorded in the Patient's Proforma. Investigations, as mentioned in the Patient's Proforma, were carried out on admission and during recovering phase of acute viral hepatitis. Fasting serum lipid profile levels of study group were compared with controls two times, once during the acute phase and then in the recovering phase of viral hepatitis.

\section{Controls}

30 healthy controls, without any clinical symptoms or liver function suggestive of acute viral hepatitis and sero-negative for hepatitis A, B, C, or E, were selected in the present study. All the controls were matched for non-modifiable risk factors such as age, gender. All the controls were selected randomly from the outpatient department under the department of medicine.

\section{Statistical Methods}

Statistical Methods Results on continuous measurements are presented on Mean \pm standard deviation and results on categorical measurements are presented in Number (\%). Significance is assessed at $5 \%$ level of significance. Student $t$ test has been used to find the significance of study parameters on continuous scale between two groups (Inter group analysis) on metric parameters. SPSS 15.0 was used for the analysis of the data and Microsoft word and Excel have been used to generate tables, graphs etc.

\section{RESULTS}

The present study is conducted among 30 probable cases of acute viral hepatitis admitted under the department of general medicine, KIMS, Karad. In this study, age of patients was ranging from 21-70 years. The maximum incidence of acute viral hepatitis was in 3rd decade (50\%). Age group distribution was almost equal in both groups. Average age of the patients was $35.5( \pm 13.89)$ years in this study. Out of 30 both among cases and controls, 22 (73.3\%) were male and 08 (26.6\%) were female. Sex distributions in case and control groups were comparable. (Table 1) (Figure 1)

In this study, HEV infection in $73.3 \%$ (22) cases was found to be the most common viral infection followed by 13.3 $\%$ (04) HAV infection, $6.66 \%$ (02) HBV infection, and $6.66 \%$ (02) HCV infection (Table 2). In this study, the majority of the cases presented with nausea/vomiting and dark yellow urine $86.6 \%$ (26) cases, followed by anorexia and icterus were in $83.3 \%$ (25) cases, abdomen pain was in $60 \%$ (18) cases, fever was in $53.3 \%$ (16) cases, hepatomegaly was in $36.6 \%$ (11) cases and pruritus was in $23.3 . \%$ cases. There was no splenomegaly in any cases. P-value $\leq 0.05$ was considered significant.

In this study in patients with acute viral hepatitis at time of acute phase, the value of Mean total cholesterol was $169.700( \pm 33.225)$, which was lower in cases than controls. While mean triglyceride was $151.066 \pm 53.677$, which was higher in cases compared to controls. The mean values of total cholesterol in cases was $32.730 \pm 37.863 \mathrm{mg} / \mathrm{dl}$ and mean value of triglyceride was $+29.933 \pm 75.019 \mathrm{mg} / \mathrm{dl}$.

In our study, among the cases, mean total cholesterol was lower in acute phase than recovering phase. The mean difference in total cholesterol was $27.266 \mathrm{mg} / \mathrm{dl}$, it was not found to be significant. Similarly, the mean triglyceride level was higher during acute phase of disease than recovering phase of disease. The difference in mean triglyceride was $10.200 \pm 42.966$, and it was also found to be non-significant.

In this study, out of 30 patients of acute viral hepatitis, $13.3 \%$ (4) were developed bleeding from gums or bleeding per rectum which was the most common complication of acute viral hepatitis, followed by hepatic encephalopathy in $6.6 \%$ (2), fulminant hepatic failure in $6.6 \%$ (2), and hepatorenal syndrome in $3.3 \% \%$ (1) cases. In this study, Total cholesterol was lower among the complicated cases than uncomplicated cases of acute viral hepatitis. Mean triglyceride was increased in complicated cases while compared to uncomplicated cases. 


\begin{tabular}{|c|c|c|}
\hline Sex & Cases No (\%) & Controls No. (\%) \\
\hline Male & $22(73.3 \%)$ & $22(73.3 \%)$ \\
\hline Female & $08(26.7 \%)$ & $08(26.7 \%)$ \\
\hline Total & $30(100 \%)$ & $30(100 \%)$ \\
\hline \multicolumn{2}{|c|}{ Table 1. Sex Distribution of Cases and Controls } \\
\hline
\end{tabular}

\begin{tabular}{|c|c|c|}
\hline Clinical Presentation & No. of Cases & Percentage (\%) \\
\hline Anorexia & 25 & $83.3 \%$ \\
\hline Nausea/ Vomiting & 26 & $86.6 \%$ \\
\hline Fever & 16 & $83.3 \%$ \\
\hline Icterus & 25 & $86.3 \%$ \\
\hline Yellow Urine & 26 & $60.0 \%$ \\
\hline Abdominal Pain & 18 & $23.3 \%$ \\
\hline Pruritus & 07 & $36.6 \%$ \\
\hline Hepatomegaly & 11 & $00 \%$ \\
\hline Splenomegaly & 00 & \\
\hline \multicolumn{2}{|c|}{ Table 2. Clinical Manifestations of Patients with Acute Viral Hepatitis } \\
\hline
\end{tabular}

\begin{tabular}{|c|c|c|c|c|}
\hline \multicolumn{2}{|c|}{ Variables } & \multirow{2}{*}{$\begin{array}{c}\begin{array}{c}\text { Mean Total } \\
\text { Cholesterol } \\
\text { (mg/dl) }\end{array} \\
169.70 \pm 33.22 \\
\end{array}$} & \multirow{2}{*}{$\begin{array}{c}\begin{array}{c}\text { Mean } \\
\text { Triglycerides } \\
\text { (mg/dl) }\end{array} \\
151.06 \pm 53.67 \\
\end{array}$} & \multirow{2}{*}{$\begin{array}{c}\text { p Value } \\
0.001 \\
\end{array}$} \\
\hline \multirow{3}{*}{$\begin{array}{c}\text { Comparison of Serum lipid levels } \\
\text { in acute phase of hepatitis with } \\
\text { controls }\end{array}$} & Cases-acute phase & & & \\
\hline & \begin{tabular}{|c|} 
Controls \\
\end{tabular} & $202.43 \pm 31.31$ & $121.13 \pm 42.26$ & 0.024 \\
\hline & $\begin{array}{c}\text { Differences(mean of lipid in case - lipid in } \\
\text { control group) }\end{array}$ & $-32.73 \pm 37.86$ & $29.93 \pm 75.01$ & 0.004 \\
\hline \multirow{3}{*}{$\begin{array}{l}\text { Serum lipid levels in cases acute } \\
\text { phase of hepatitis }\end{array}$} & \begin{tabular}{|c|} 
Acute phases \\
\end{tabular} & $169.70 \pm 3.22$ & $151.06 \pm 53.67$ & 0.001 \\
\hline & Recovering phases & $196.96 \pm 48.85$ & $140.86 \pm 29.23$ & 0.018 \\
\hline & Differences & $-27.26 \pm 52.17$ & $10.20 \pm 42.96$ & 0.016 \\
\hline \multirow{2}{*}{$\begin{array}{c}\text { Complicated Vs Uncomplicated } \\
\text { viral hepatitis }\end{array}$} & Complicated viral hepatitis & $160.25 \pm 10.21$ & $160.25 \pm 8.71$ & 0.017 \\
\hline & Uncomplicated viral hepatitis & $171.15 \pm 35.37$ & $149.65 \pm 56.09$ & 0.022 \\
\hline \multirow{4}{*}{ Aetiology } & HAV & $166.5 \pm 38.55$ & $154.5 \pm 61.59$ & 0.014 \\
\hline & HBV & $155.5 \pm 38.02$ & $135.0 \pm 84.12$ & 0.001 \\
\hline & $\mathrm{HCV}$ & $196.5 \pm 36.81$ & $128.5 \pm 13.94$ & 0.004 \\
\hline & HEV & $169.13 \pm 33.22$ & $153.95 \pm 53.67$ & 0.012 \\
\hline \multirow{2}{*}{ Hospital stay } & $\begin{array}{l}\text { Patients who required hospital stay } \leq 7 \\
\text { days }\end{array}$ & $174.20 \pm 35.37$ & $152.16 \pm 56.09$ & 0.023 \\
\hline & $\begin{array}{c}\text { Patients who required hospital stay }>7 \\
\text { days }\end{array}$ & $151.66 \pm 28.56$ & $146.66 \pm 27.69$ & 0.004 \\
\hline
\end{tabular}

\begin{tabular}{|c|c|c|c|c|c|c|c|}
\hline \multirow{2}{*}{$\begin{array}{c}\text { Lipid } \\
\text { Parameter }\end{array}$} & \multicolumn{2}{|c|}{ Present Study } & \multicolumn{2}{|c|}{ Bhattacharya et al[ 128] } & \multicolumn{2}{|c|}{ Abbas al-Tamimi et al [127] } & \multirow[t]{2}{*}{ p Value } \\
\hline & Cases & Controls & Cases & Controls & Cases & Controls & \\
\hline $\begin{array}{c}\text { Mean total } \\
\text { cholesterol } \\
(\mathrm{mg} / \mathrm{dl})\end{array}$ & $\begin{array}{c}169.700 \pm \\
33.225\end{array}$ & $\begin{array}{c}202.430 \pm \\
31.313\end{array}$ & $\begin{array}{l}228.84 \pm \\
31.34\end{array}$ & $90.68 \pm 24.19$ & $148.36 \pm 42.26$ & $215.34 \pm 75.85$ & 0.024 \\
\hline $\begin{array}{c}\text { Mean triglycerides } \\
(\mathrm{mg} / \mathrm{dl})\end{array}$ & $\begin{array}{c}151.066 \pm \\
53.677 \\
\end{array}$ & $\begin{array}{c}121.133 \pm \\
42.266 \\
\end{array}$ & $\begin{array}{c}164.6 \pm \\
70.82 \\
\end{array}$ & $111.18 \pm 24.15$ & $254.86 \pm 120.8$ & $247.04 \pm 135.3$ & 0.014 \\
\hline \multicolumn{8}{|c|}{ Table 4. Correlation of Complications of Acute Viral Hepatitis with Lipid Parameters } \\
\hline
\end{tabular}

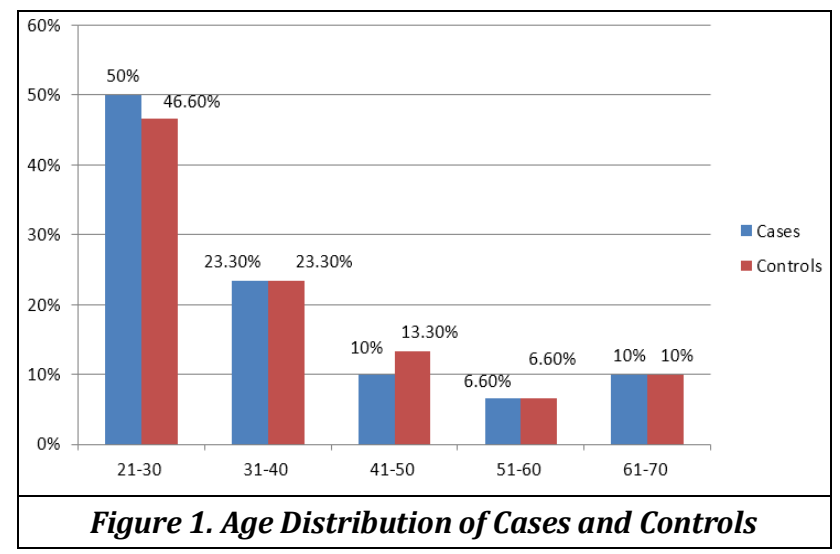




\section{DISCUSSION}

The present study is conducted among probable cases of acute viral hepatitis, with an objective to study clinical presentations of various acute viral hepatitis (viz. Hepatitis $\mathrm{A}$, $\mathrm{B}, \mathrm{C}, \mathrm{D}$ and $\mathrm{E}$ ), and hence to correlate the diagnosis with liver profile levels. In this study we enrolled total 30 cases and 30 controls, who were matched for age, gender and risk factors. Mean age for these cases was $35.50 \pm 13.89$ years and in controls it was $35.86 \pm 13.66$ years. The mean ages are comparable between the cases and control groups. In a study by Abbas al-Tamimi et al,[5] total number of cases were 63 and the mean age in cases was 30.3 years and in controls it was 36.16 years which can be compared to our study. In the Bhattacharya et al[6] study, total 100 subjects were studied (50 cases, 50 controls). The mean age in cases was 25.68 years while in controls it was 24.2 years (Table 5). In our study, out of 30 cases, $73 \%$ cases were male, while $27 \%$ were female, while in Bhattacharya ${ }^{[6]}$ study $48 \%$ cases were male, and $52 \%$ cases were female.

In this present study, the more common clinical manifestations were nausea/vomiting and dark yellow urine which were present in $86.6 \%$ (26) cases, followed by anorexia and icterus were in $83.3 \%$ (25) cases, abdomen pain was in $60 \%$ (18) cases, fever was in $53.3 \%$ (16) cases, hepatomegaly was in $36.6 \%$ (11) cases and pruritus was in 23.3.\% cases. There was no splenomegaly in any cases. Most common symptoms in Bhattacharya et al[6] were jaundice and yellow coloured urine -were present in all (100\%) cases followed by anorexia in $90 \%$ cases, hepatomegaly in $72 \%$ cases, nausea/vomiting and fever in $70 \%$ cases, abdomen pain in $30 \%$ cases and pruritus in $20 \%$ cases (Table 4 ).

Mean total cholesterol level in our study during acute phase of viral hepatitis, was $169.700 \pm 33.225 \mathrm{mg} / \mathrm{dl}$, whereas it was $228.84 \pm 31.34 \mathrm{mg} / \mathrm{dl}$ in the Bhattacharya [6] study and $148.36 \pm 42.26 \mathrm{mg} / \mathrm{dl}$ in the Abbas al-Tamimi[5] study. Among the controls mean total cholesterol was $202.430 \pm 31.313$ $\mathrm{mg} / \mathrm{dl}$ in our study whereas it was $90.68 \pm 24.19 \mathrm{mg} / \mathrm{dl}$ in the Bhattacharya study ${ }^{[6]}$ and $215.34 \pm 75.85 \mathrm{mg} / \mathrm{dl}$ in the Abbas al-Tamimi[5] study. In our study, mean total cholesterol was lower in acute phase of viral hepatitis, which was same as in Abbas al-Tamimi[5] study. While in Bhattacharya[6] study mean total cholesterol was higher in acute phase. Mean serum total cholesterol level in complicated cases was 160.25 $\pm 10.210 \mathrm{mg} / \mathrm{dl}$ which was lower than uncomplicated cases, contrary to the Bhattacharya et al[6] study. Our study showed that there is no significant change in serum total cholesterol levels among acute phase and among controls.

Mean triglycerides level in this study among cases during acute phase of viral hepatitis, was $151.066 \pm 53.677 \mathrm{mg} / \mathrm{dl}$, whereas it was $164.6 \pm 70.82 \mathrm{mg} / \mathrm{dl}$ in the Bhattacharya [6] study and $254.86 \pm 120.8 \mathrm{mg} / \mathrm{dl}$ in the Abbas al-Tamimi[5] study. Among the controls, mean triglycerides was $121.133 \pm$ $42.266 \mathrm{mg} / \mathrm{dl}$ in this study whereas it was $111.18 \pm 24.15$ $\mathrm{mg} / \mathrm{dl}$ in the Bhattacharya study[6] and $247.04 \pm 135.3 \mathrm{mg} / \mathrm{dl}$ in the Abbas al-Tamimi [5] study. Thus, in our study, triglycerides were higher in acute phase, which was same as Bhattacharya [8] study Abbas al-Tamimi [5] study. Mean serum triglyceride level in complicated cases was $160.25 \pm 38.715$ $\mathrm{mg} / \mathrm{dl}$ which was higher than uncomplicated cases, same as the Bhattacharya et al[6] study. Our study showed that there is no significant change in serum triglyceride levels among acute phase and among controls. The significant decline in the serum total cholesterol and TG levels in cirrhotic patients compared with healthy people has been confirmed earlier in other studies, which is reasonably expected since liver biosynthesis has been reduced. For instance, the same results were obtained in a study by Mehbob I, et al[7], in 2007, who studied 160 patients with chronic liver diseases. There were significant declines in the serum total cholesterol and TG levels of patients. Another study in Greece was performed by Siagris ${ }^{[8]}$ on 155 patients infected with HCV and 138 healthy people who served as the comparison group, where the serum total cholesterol level was lower in patients than the comparison group.

In this study, out of 30 patients of acute viral hepatitis, $13.3 \%$ (4) developed gum bleeding or per rectum bleeding which was the most common complication of acute viral hepatitis, followed by hepatic encephalopathy in $6.6 \%$ (2), fulminant hepatic failure in $6.6 \%$ (2), and hepato-renal syndrome in $3.3 \% \%$ (1); while Bhattacharya et al[6] study, most common complication was hepatic encephalopathy present in $6 \%$ cases, followed by GI bleed and fulminant hepatic failure in $4 \%$ cases.

In our study, HEV infection in $73.3 \%$ (22) cases were found to be the most common viral infection followed by 13.3 $\%$ (04) HAV infection, $6.66 \%$ (02) HBV infection, and $6.66 \%$ (02) HCV infection; while in Bhattacharya study[6] HEV infection in $30 \%$ cases were found to be most common viral infection followed by HAV in $25 \%$, HBV in $14 \%$ and HCV in $4 \%$ cases.

There was no correlation found in any lipid profile parameters in the study during acute phase in relation to etiological agent of viral hepatitis.

\section{CONCLUSIONS}

In acute phase of viral hepatitis, there is a significant decrease in mean total cholesterol levels, while the mean triglyceride is higher in acute phase. Mean total cholesterol levels were lower in this study in the acute phase than recovering phase of viral hepatitis. Lipid parameters were deranged in acute viral hepatitis as compared to controls, more deranged in acute phases of acute viral hepatitis than recovering phases of viral hepatitis and in complicated cases, as compared to uncomplicated cases, so we can use serum lipid profile as a prognostic marker in acute viral hepatitis.

\section{REFERENCES}

[1] Jain P, Prakash S, Gupta S, et al. Prevalence of hepatitis A virus, hepatitis $B$ virus, hepatitis $C$ virus, hepatitis D virus and hepatitis $\mathrm{E}$ virus as causes of acute viral hepatitis in North India: a hospital based study. Indian J Med Microbiol 2013;31(3):261-5.

[2] Irshad M, Singh S, Ansari MA, et al. Viral hepatitis in India: a report from Delhi. Glob J Health Sci 2010;2(2):96-103.

[3] Kaur R, Gur R, Berry N, et al. Etiology of endemic viral hepatitis in urban North India. Southeast Asian J Trop Med Public Health 2002;33(4):845-8.

[4] Poddar U, Thapa BR, Prasad A, et al. Changing spectrum of sporadic acute viral hepatitis in Indian children. J Trop Pediatr 2002;48(4):210-13. 
[5] Al-Tamimi AAA, Kamil YM. A study for the changes of lipid profile in sera of patients infected with viral hepatitis type B and C infections. Biology dept., college of science; Al-Mustansiriyah University 2013:185-96.

[6] Bhattacharya PK, Tomke RD, Saikia H. Lipid profile in acute viral hepatitis: a study from north eastern India. International Journal of Biomedical and Advance Research 2016;7(8):379-82.
[7] Irshad M, Dube R, Joshi YK. Impact of viral hepatitis on apo- and lipoprotein status in blood. Med Princ Pract 2007;16(4):310-4.

[8] Siagris D, Christofidou M, Theocharis GJ, et al. Serum lipid pattern in chronic hepatitis C: histological and virological correlations. J Viral Hepat 2006;13(1):5661. 